\section{Halvor Nordby}

Professor Høgskolen i Lillehammer Avdeling for helse- og sosialfag og Universitetet $i$ Oslo Det medisinske fakultetet Institutt for helseledelse og helseøkonomi.

Et enkelt spørsmål som «Hvordan går det med deg?» kan ofte være det som skal til for at pasienter foler at de står overfor en empatisk person.

\title{
Oppfatter pasienten
}

\section{www.sykepleien.no}

Les mer og finn

litteraturhenvisninger på

www.sykepleien.no

\section{Søkeord:}

Kommunikasjon

Felles språk

Oppmerksomhet

Assosiative misforståelser

Verdier 


\section{det du sier?}

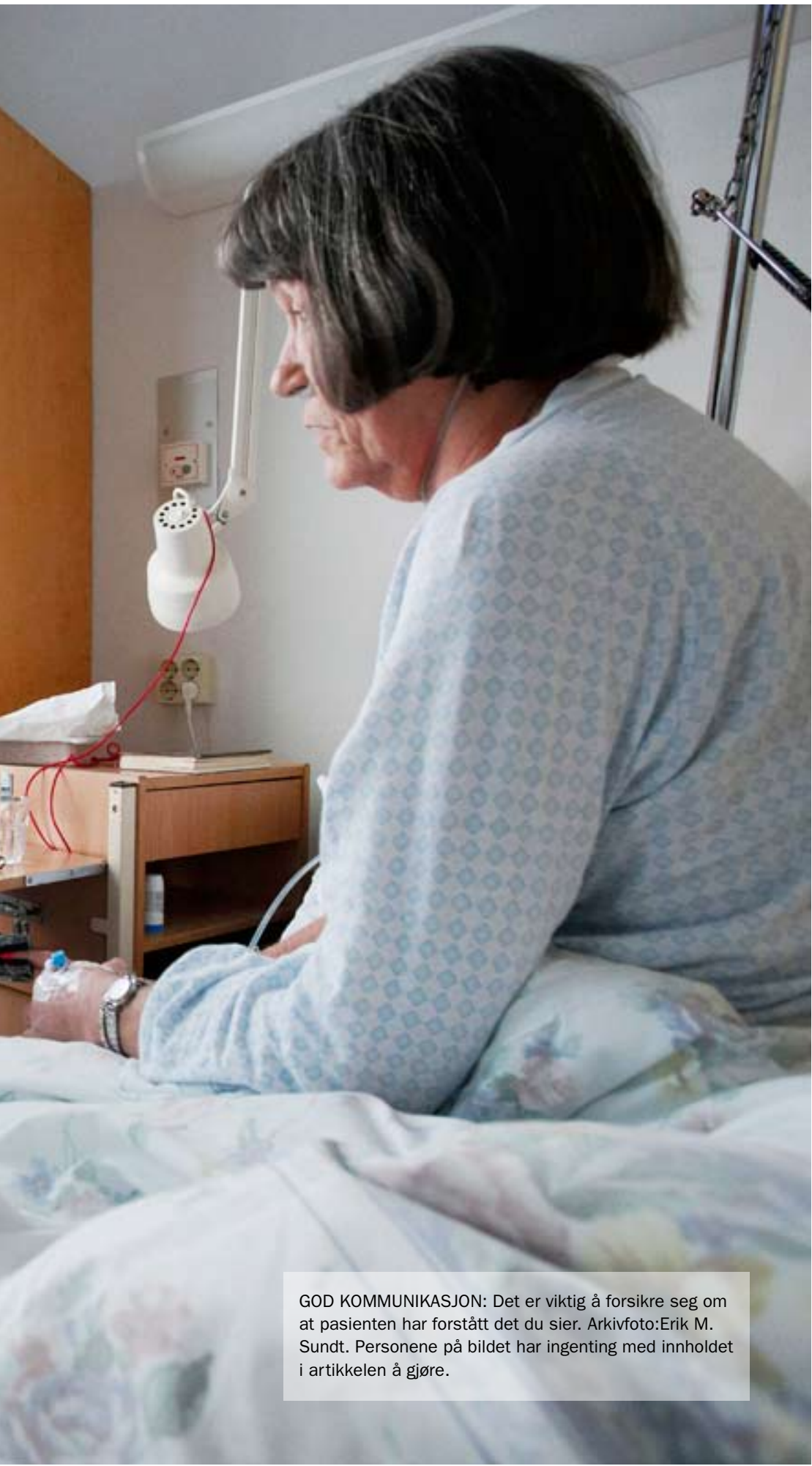

\section{Det er viktig å sikre god pasientkommunikasjon, og det er ofte relativt enkelt for sykepleiere å danne seg en oppfatning av hvorvidt kommunikasjonsbe- tingelsene er møtt.}

Artikkelen bruker antagelser om språk og bevissthet fra filosofisk psykologi til å skille mellom fire grunnleggende kommunikasjonsbetingelser som det er viktig for sykepleiere å være oppmerksomme på. Den første handler om nødvendigheten av å ha et felles språk, den andre om å ha pasientens oppmerksomhet, den tredje om å unngå det man kan kalle «assosiative misforståelser» og den fjerde om kommunikasjon av verdier, emosjoner og holdninger. Artikkelen klargjør forholdet mellom disse betingelsene og forklarer hvorfor det er viktig for sykepleiere å ha et bevisst forhold til dem.

\section{Språk}

Hvis en sykepleier ikke uttrykker et budskap på en måte som en pasient forstår - hvis de ikke knytter den samme meningen til sykepleierens verbale eller ikke-verbale språklige handlinger - så finnes det ikke en felles språkplattform som interaksjonen kan være basert på $(1,2,3)$. Det samme poenget gjelder selvsagt den andre veien i relasjonen. Hvis en pasient uttrykker et budskap ved hjelp av kroppsspråk eller verbalt språk sykepleieren ikke klarer å forstå, så er kommunikasjon grunnleggende mislykket.

Rene språklige misforståelser oppstår lett når pasienter eller sykepleiere snakker dårlig norsk. Men selv i tilfeller hvor begge parter behersker godt det samme språket, kan språklige misforståelser lett oppstå. Hovedgrunnen er at den typiske sykepleier-pasient-interaksjon involverer to typer språklige uttrykk $(4,5)$. Den første er det man kan kalle vanlige medisinske uttrykk som intravenøs, infeksjon og diabetes. Sykepleiere og andre helsearbeidere som har et hverdagslig forhold til disse uttrykkene kan lett glemme at pasienter og pårørende ofte har en relativt svak forståelse av dem. Pasienter kan dessuten synes det er litt flaut å spørre hva uttrykkene betyr hvis de synes de møter en forventning om at «alle vet vel hva de betyr». Den andre typen språklige uttrykk som lett kan skape språklige misforståelser er lekmannshelseuttrykk som ikke har presise definisjoner selv innenfor helsevesenet. Det er godt dokumentert at pasienters forståelse av subjektive ord som smerte, vondt, kvalme og svimmel er formet av deres sosiale og kulturelle kontekst $(6,7,8)$. Hvis en pasient ikke direkte svarer bekreftende på spørsmål om han har «veldig vondt», og hvis grunnen er at han i virkeligheten har en høyere terskel for bruk av ordet «vondt» enn det sykepleieren tror, så vil sykepleieren ha et feilaktig bilde av den tilstanden pasienten uttrykker.

Det er viktig at sykepleiere har en varhet for når språklige misforståelser er i ferd med å oppstå. Spesielt når bruk av medisinske uttrykk spiller en avgjørende rolle i den forstand at de utløser handlinger. Vurderinger rundt smertestillende med- 
ikamenter ut fra en pasients bruk av ordet «vondt», bør for eksempel gjøres ut fra en utfyllende klargjøring av hvordan pasienten forstår ordet. En praktisk handlingsregel kan formuleres på følgende måte: Hvis det er tvil om hvordan en pasient forstår et språklig uttrykk, og hvis bruken av uttrykket spiller en viktig handlingsveiledende rolle for en sykepleier, så bør potensielle språklige misforståelser avdekkes og oppklares.

Sykepleiere vil normalt ikke bruke et spesielt medisinsk vokabular uten å forklare hva det betyr. Man forventer ikke at pasienter har en god forståelse av fremmede uttrykk, og de fleste er flinke til å unngå så åpenbar dårlig kommunikasjon. Det er lettere å gå i språklige feller når det gjelder mer vanlige uttrykk. I en hektisk yrkeshverdag er det ikke alltid så lett å huske at uttrykk, som for sykepleiere fortoner seg dagligdagse og uproblematiske, kan være ganske fremmede for pasienter. Både leger og sykepleiere vil nok kunne si «Det er ikke noe i veien med blodtrykket ditt» uten å forklare nærmere hva «blodtrykk» betyr. Men mange pasienter, og spesielt pasienter uten en lang sykdomshistorie, har ofte en vag forståelse av ordet. Og i så fall har man ikke klart å kommunisere så mye som man kanskje tror.

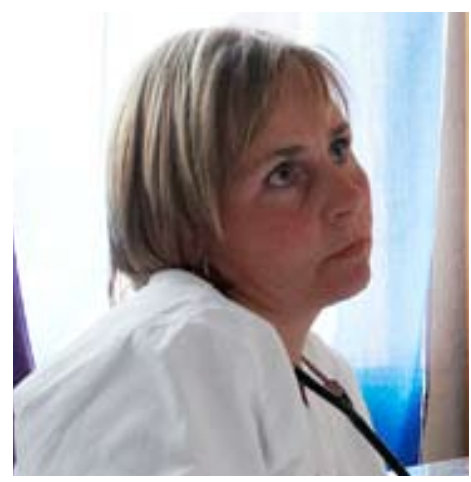

\section{Oppmerksomhet}

Felles språkplattform er nødvendig, men ikke en tilstrekkelig betingelse for vellykket kommunikasjon. Budskapet som sykepleieren forsøker å kommunisere må virkelig nå frem til pasientens bevissthet $(9,10,11)$.

En rekke faktorer kan gjøre at sykepleier ikke har pasientens fulle oppmerksomhet. Pasienten kan være mer omtåket og ha større problemer med å fokusere enn man tror $(2,9)$. Pasienten kan også ha nedsatt evne til å tenke rasjonelt og bearbeide omfattende informasjon. Problemet kan også oppstå den andre veien i relasjonen. Man hører noen ganger om pasienter som klager over at helsepersonell holder på med andre ting mens de tilsynelatende kommuniserer. For eksempel ved resepsjoner i sykehusavdelinger hvor sykepleiere registrerer pasientinformasjon mens de snakker med pasienter. For pasienter kan det føles ganske frustrerende å legge ut om personlige og private helseplager, hvis de føler at de ikke har helsepersonells fulle oppmerksomhet.

Kommunikasjon fra sykepleier til pasient er grunnleggende mislykket hvis sykepleieren tror at informasjon har nådd frem til pasientens bevissthet, mens det i virkeligheten ikke har skjedd $(9,10)$. En viktig grunn til at slike misforståelser lett oppstår er at mange pasienter har problemer med å bearbeide det som har blitt sagt, spesielt i forhold til detaljert og ukjent informasjon. Pasienter kan ofte klare å forstå det som blir sagt der og da, men like fullt ha store problemer med å huske det i ettertid. Mot slutten av en samtale bør man ofte oppsummere den viktigste informasjonen som er gitt. Og hvis det er tvil bør man kontrollere at denne informasjon virkelig har nådd frem til pasientens bevissthet.

Et annet poeng er at pasienter ofte har mer enn nok med å klare «å være til stede» $(12,13)$. Møter med helsevesenet oppleves ofte fremmed og ukjent og er i stor grad preget av usikkerhet og emosjoner. En stor del av pasienters mentale kapasitet blir brukt til å bearbeide sykdomsopplevelser og forskjellige sanseinntrykk i møtet med et komplekst system. Det er viktig å huske at selv pasienter som ikke har akutt skade eller sykdom kan trenge tid og hjelp til å «senke skuldrene» i møte med sykepleiere og annet helsepersonell.

Enda mer utfordrende blir det selvsagt når helsepersonell står overfor pasienter eller pårørende $\mathrm{i}$ krise (14). Hvis det er rimelig tvil bør man derfor avklare om det er noe helt spesielt pasienten lurer på. Det betyr ikke at man må ha et endelig svar på det de spør om. «Det er vanskelig å si noe nå» kan ha en beroligende effekt, spesielt hvis pasienten i første omgang trodde at sykepleieren hadde et mer konkret svar.

\section{Assosiasjoner}

Det tredje problemet som kan oppstå er at pasienten danner seg helt andre oppfatninger om sykepleierens budskap enn det sykepleieren mener å kommunisere.

Utfordringen for sykepleiere og annet helsepersonell er at pasienter vanligvis tillegger det som uttrykkes i språk mer enn det som blir sagt. Dette er et vanlig fenomen som faller inn under et generelt prinsipp om at avsendere i kommunikasjonsprosesser forsøker å være så økonomiske som mulig i sin kommunikasjon $(15,16)$. Ideen er at både avsendere og mottagere $\mathrm{i}$

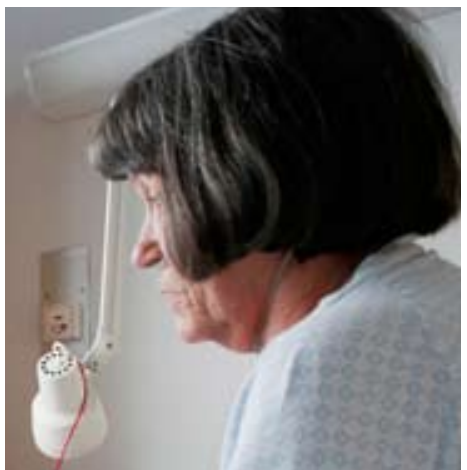

kommunikasjonsprosesser tilpasser seg dette prinsippet (15). Det vil si, avsendere uttrykker bare det de tror de trenger for å kommunisere det de ønsker, og fortolkningene til mottagere vil normalt inneholde mye mer enn det avsender faktisk sier (17). På mange måter kan man si at verbalt språk vanligvis oppfattes som toppen av isfjellet $i$ mellommenneskelig kommunikasjon. Med utgangspunkt i avsenders kroppsspråk, konteksten man er i og antagelser om avsender, former avsender fortolkninger som går langt utover det som direkte kommer til syne i språk.

En viktig handlingsregel for sykepleiere og annet helsepersonell er derfor å tydeliggjøre hva de legger i vage påstander. Spesielt når det er grunn til å tro at pasienter kan tolke påstandene for negativt eller positivt, og når det ikke er grunnlag for å tolke dem i den ene eller andre retningen. Når det er rimelig grunn til tvil om dette er i ferd med å skje, bør sykepleiere forvisse seg om at budskapet blir forstått på den måten det er tilsiktet.

\section{Sykdomsopplevelser, verdier og holdninger}

En fjerde kommunikasjonsbetingelse bør til slutt nevnes: Avsendere i kommunikasjonsprosesser forsøker ofte å kommunisere følelser, verdier og holdninger. Vellykket kommunikasjon forutsetter at mottagere forstår hvilke følelser, verdier og holdninger avsendere uttrykker.

Et eksempel kan være en pasient som ønsker å kommunisere til en sykepleier hvordan en tilstand av smerte oppleves. Selve opplevelsen 


\section{Uttrykk som for sykepleiere fortoner seg dagligdagse $0 \mathrm{~g}$ uproblematiske kan være ganske fremmede for pasienter.}

av å ha smerte er ikke en oppfatning, men en subjektiv erfaring (17). Misforståelse oppstår hvis sykepleieren tror at den erfaringen pasienten uttrykker har en helt annen natur enn det pasientens smertetilstand virkelig har. På samme måte er det mulig å misforstå hvordan pasienter opplever tilstander som kvalme, ubehag og svimmelhet, og også mer generelle plager som angst og uro (2).

For sykepleiere er det viktig å huske at pasienters verdier og måten de uttrykkes på er formet av deres egen sosiale og kulturelle bakgrunn. Manglende kulturforståelse og kultursensitivitet kan giøre at helsepersonell misforstår hvordan pasienter verdsetter å bli behandlet. Pasientens sosiokulturelle normer samsvarer ikke nødvendigvis med normene helsepersonell baserer interaksjonen på $(6,7)$.

Denne type tilskrivelse av verdier pasienter i virkeligheten ikke har, er et fenomen som det er viktig å tenke på for de som ukritisk legger sine egne eller "politisk korrekte» verdier til grunn i pasientinteraksjon. Fundamentale misforståelser og dårlig kommunikasjon oppstår lett hvis sykepleiere uten videre tror at «våre» eller «norske» verdier er universelle verdier.

Et annet fenomen som bør nevnes er tilskrivelser av holdninger som empati, omsorg og omtanke. Hvis en pasient tror at en sykepleier ikke er empatisk, og hvis sykepleieren faktisk mener å uttrykke empati i ord eller handlinger, så har en grunnleggende misforståelse oppstått. Det er derfor viktig at sykepleiere ikke bare forstår og anerkjenner pasienters sykdomsopplevelser. Man må faktisk vise empati - ellers kan pasienter lett tro at man ikke er empatisk. Et enkelt spørsmål som «Hvordan går det med deg?» kan ofte være det som skal til for at pasienter føler at de står overfor en empatisk person (14).

På samme måte er det viktig å unngå tilskrivelser av negative holdninger. Hvis en pasient tror at en sykepleier som sier «Det går mye bedre med deg nå», egentlig ikke mener det som sies og sykepleieren faktisk mener å være oppriktig, så har en grunnleggende misforståelse oppstått. Denne typen misforståelser oppstår gjerne i inkongruent kommunikasjon - hvis pasienten opplever at sykepleierens kroppsspråk ikke passer med det som sies. Problemet med inkongruent kommunikasjon er at vi har lett for å tro at sannheten ligger i avsenders kroppsspråk (19) - og at avsender faktisk mener det motsatte av det som sies. Tilskrivelser av negative holdninger som mistillit og manglende oppriktighet fordi kroppsspråket ikke støtter det budskapet som uttrykkes i ord, vil derfor i spesielt stor grad skape en dårlig relasjon mellom sykepleier og pasient.

\section{Spørsmål i praksis}

De fire grunnleggende kommunikasjonsbetingelsene denne artikkelen har fokusert på er ofte relevante i pasientinteraksjon. Ved å ha forholdet mellom disse klart for seg kan det være enklere for sykepleiere å forholde seg til situasjoner som involverer utfordrende kommunikasjon. I tillegg er det fire spørsmål det er viktig å være oppmerksom på i praksis:

1) Har vi en tilfredsstillende lik språkforståelse?

- Hvis det er rimelig tvil bør man klargjøre sin egen og pasientens forståelse.

2) Har jeg pasientens oppmerksom- het, og er jeg oppmerksom på det pasienten sier?

- Hvis det er rimelig tvil bør man sikre seg at budskapet når frem. 3) Hvordan tolker pasienten det jeg sier og hvordan forstår jeg pasienten?

- Hvis det er rimelig grunn til å tro at pasienten får helt andre assosiasjoner rundt det som sies enn det som er tilsiktet, bør man klargjøre sine egne assosiasjoner. På samme måte, hvis det ikke er klart hvilke oppfatninger pasienten egentlig mener å kommunisere, så bør man avdekke hvilke oppfatninger pasienten har.

4) Er jeg i ferd med å bli tilskrevet holdninger eller verdier jeg ikke har, eller tilskriver jeg pasienten holdninger, verdier eller sykdomsopplevelser pasienten ikke har? - Hvis det er tvil bør man klargjøre sine egne holdninger og verdier og på samme måte forsøke å avklare hvilke holdninger, verdier og sykdomsopplevelser pasienten har.

Dette kan forstås som en mental plakat sykepleiere kan ha $\mathrm{i}$ bakhodet - en praktisk sjekkliste for å sikre god pasientkommunikasjon. Spørsmålene og måtene man kan sikre seg at svarene er tilfredsstillende på kan virke enkle. Men ved å være flink til å bruke dem i praksis kan man forebygge mange unødvendige misforståelser. Kunnskap om kommunikasjonsbetingelsene løser selvsagt ikke alle problemer som kan oppstå $\mathrm{i}$ pasientinteraksjon. Men poenget er at betingelsene er relevante og anvendbare i en rekke situasjoner som involverer utfordrende kommunikasjon.

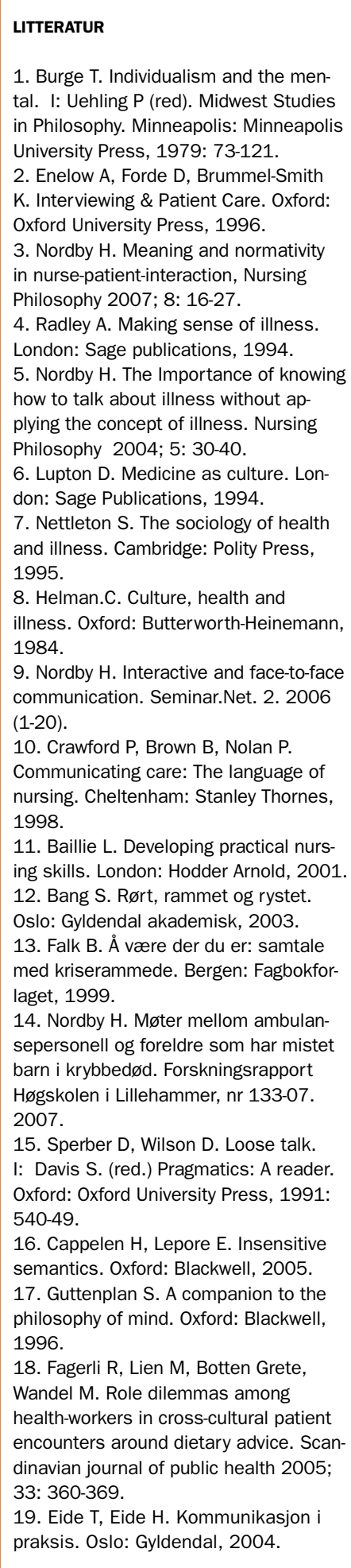

